\title{
NATURAL RESOURCES AND TEACHING TRANSNATIONAL COMMERCIAL LAW
}

\author{
Thomas KeIJSER*
}

\section{CONTENTS}

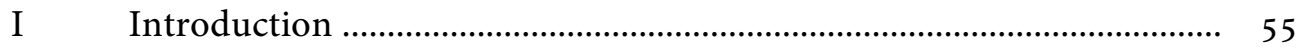

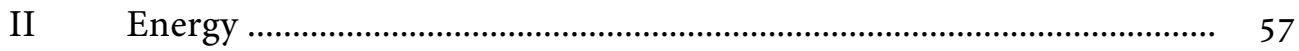

III Extraction of Resources and Deforestation ........................................... 59

IV Newly Created Materials: Plastics ....................................................... 61

V Food: Transgenetic Modification …………………………………........ 62

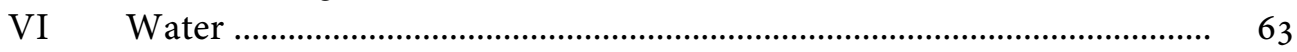

VII The Atmosphere: Radiation ……………….......................................... 65

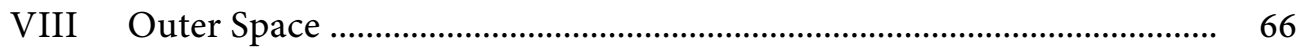

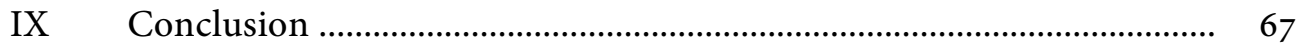

\section{INTRODUCTION}

"Once a photograph of the Earth, taken from the outside, is available ... a new idea as powerful as any in history will be let loose."

Fred Hoyle (1948); opening quote of Guy Reid

(documentary director), Overview (2012)

"Science does not necessarily equal wisdom."

$$
\begin{aligned}
& \text { Herbert Kronke, in the context of the 5th } \\
& \text { Transnational Commercial Law teachers' } \\
& \text { conference in Kyushu, Japan (2013) }
\end{aligned}
$$

"The right use of natural resources, the proper application of technology and the harnessing of the spirit of enterprise are essential elements of an economy which seeks to be modern, inclusive and sustainable."

Address of Pope Francis to US Congress (24

September 2015)

\footnotetext{
Senior Researcher, Business \& Law Research Centre, Radboud University Nijmegen, The Netherlands. This article is based on a paper presented at the 7 th Transnational Commercial Law Teachers' Conference in Perth, Australia, on 26 November 2015.

${ }^{* *}$ This address builds on the Encyclical Letter Laudato Si' of the Holy Father Francis on Care for Our Common Home (2015).
} 
One of the major challenges of our time is addressing the impact of commerce on natural resources worldwide. The industrial and technological revolutions and related paradigms such as (short-term) profits for shareholders, competition, and 'growth' have, paradoxically, had unintentional yet farreaching, if not devastating, consequences for virtually all natural resources (or, to put it in less economically inspired terms, for whatever form of natural wealth or riches), including the earth's land surface and its deeper layers, vegetation and wildlife, oceans, seas and other water resources, the atmosphere, and even outer space. Nonetheless, education for commercial and financial lawyers typically focuses on the technicalities of commercial and financing constructions, paying no heed to the (potentially) calamitous consequences these may have. This essay proposes a method to make the issue of natural resources an integral part of the commercial and financial law curriculum, contributing to the education of a new generation of commercial and financial lawyers that has been equipped with the knowledge to make responsible choices.

The approach here identified is to integrate case studies that in one way or another relate to natural resources into mainstream commercial and financial law courses. It is explicitly not intended to propose the creation of separate courses on the issue, as these are likely to reach only a limited group of students with a specific focus of interest. The sample case studies presented below are roughly organized as per a broad range of natural resources. They aim at familiarizing students with a variety of commercial and financial law aspects relating to natural resources. 'Commercial and financial law' is broadly understood as any legal issue concerning commercial activity, including issues in the realm of civil law, liabilities, intellectual property law, financing constructions, criminal law, State/regulatory law, constitutional law, public international law, private international law, human rights, dispute resolution, etc. Some reading material and other sources are listed for each case to illustrate the (scientific, economic, social, legal, or other) debate in relation to the issue concerned, but students should search for additional legal background material. In many of the cases no jurisdiction has been chosen in order to keep this text 'neutral', but when actually working with students such a choice is likely to be instrumental. Clearly, further case studies could be devised, concerning a variety of legal issues relating to other natural resources. 


\section{ENERGY}

A broad variety of energy sources, including fossil fuels (oil, coal, gas) and wind, solar, biomass, tidal and wave power, are currently (still) available or being developed. Each of these sources has its advantages and disadvantages. ${ }^{1}$

Case 1. A broad body of scientific studies singles out fossil fuels as a primary cause of climate change. The Oslo Principles on Global Climate Change Obligations, on the basis of canons of inter alia international human rights law, environmental law and tort law, identify obligations of States and enterprises (including enterprises in the banking and finance sector) in the context of global warming. ${ }^{2}$ Students are asked to investigate whether and how this approach can be applied in the context of different industry sectors, such as the extraction of rare minerals (see Case 7) and agriculture (see section V), and to identify obligations of States and enterprises in these sectors. The results proposed by the Oslo Principles and for the other industry sectors could be compared in the context of in-class presentations.

Case 2. In several countries, judicial proceedings have been or are being conducted to force States and enterprises to ensure a viable biosphere in the future. Students are asked to draw up a risk analysis for their employer, a major energy company, interested in possible future policy developments due to climate change. In particular, students should identify the legal strategies (eg tort, a government's duty of care towards its citizens, public trust, public nuisance, human rights invasions, invalidity of permits, classification as a toxic substance, etc) underlying court cases regarding climate change in the Netherlands, the United States, and elsewhere. ${ }^{3}$

\footnotetext{
${ }^{1}$ See, Roger Harrabin, 'Moon Shot' Call on Clean Energy (2 June 2015)

$<$ http://www.bbc.com/news/science-environment-32967386>; Matt McGrath, US Wild Bee Numbers Decline As Land Is Converted for Biofuel (22 December 2015) $<$ http://www.bbc.com/news/scienceenvironment-35153196>; Oxford Geoengineering Programme, What Is Geoengineering? (2016) $<$ http://www.geoengineering.ox.ac.uk/what-is-geoengineering/what-is-geoengineering/> (on geoengineering, i.e., on the, one hopes, fictional consequences of continued excessive emissions of greenhouse gasses).

${ }^{2}$ See, Oslo Principles on Global Climate Change Obligations (1 March 2015)

$<$ http://www.osloprinciples.org/>; Julia Powles and Tessa Khan, Climate Change: At Last a Breakthrough to Our Catastrophic Political Impasse? (30 March 2015) $<$ http://www.theguardian.com/commentisfree/2015/mar/30/climate-change-paris-talks-osloprinciples-legal-obligations $>$.

${ }^{3}$ See, Michael Gerrard, 'Scale and Focus of Climate Litigation Outside of United States', New York Law Journal 253/47 (12 March 2015)
} 
Case 3. One (potential) energy source are sea currents and/or waves. ${ }^{4}$ Students are asked to write an essay in which they identify legal aspects of generating such energy. These may include inter alia financing aspects of equipment needed; public international law aspects (whose is the sea territory where the necessary instruments are installed?); liability for cleaning up the equipment or for paying any damage caused (e.g., where the equipment damages a vessel or its cargo belonging to a company in another State).

Besides authoritative guidelines such as the Oslo Principles on Global Climate Change Obligations and court cases regarding the role of the State in guaranteeing a viable biosphere, some States have taken a novel approach on the issue in their legislation. ${ }^{5}$ For example, the Constitution of Ecuador introduced a chapter on the rights of nature in $2008^{6}$, while Bolivia enacted a Law on the Rights of Mother Earth in 2010. ${ }^{7}$ Moreover, criminal law has been proposed as a tool to establish the limits of acceptable (corporate) behaviour. ${ }^{8}$ This raises the question of how such legislative approaches relate to the imperatives of doing business.

$<$ http://web.law.columbia.edu/sites/default/files/microsites/climatechange/nyljscaleandfocusofclimatelitigationoutsideofunitedstates.pdf $>;$ Netherlands Ordered to Cut Greenhouse Gas Emissions (24 June 2015) <http://www.bbc.com/news/world-europe-33253772>; Urgenda $<$ http://www.urgenda.nl/en/climate-case/> on the case Urgenda vs The Netherlands, including translations of the case files; Eric Holthaus, The Point of No Return: Climate Change Nightmares Are Already Here (5 August 2015) <http://www.rollingstone.com/politics/news/thepoint-of-no-return-climate-change-nightmares-are-already-here-20150805> (on some court cases in the US, see the last three paragraphs); Superior Court of the State of Washington for King County, case no. 14-2-25295-1 SEA of Zoe and Stella Foster et al. (petitioners) vs Washington Department of Ecology (respondent); Republic of the Philippines, Supreme Court, verdict G.R. No. 101083 (30 July 1993) < http://www.lawphil.net/judjuris/juri1993/jul1993/gr_101083_1993.html> (setting out the 'Oposa doctrine' on inter-generational justice).

${ }^{4}$ See, Richard Anderson, Riding the Waves: The Challenges of Harnessing Ocean Power (17 March 2015) <http://www.bbc.com/news/business-31651019>.

${ }^{5}$ See, Lorenzo Fioramonti et al., Say Goodbye to Capitalism: Welcome to the Republic of Wellbeing (2 September 2015) <http://www.theguardian.com/sustainable-business/2015/sep/o2/say-goodbyeto-capitalism-welcome-to-the-republic-of-wellbeing $>$ (with references to statutory approaches in Bolivia, Ecuador, and New Zealand).

${ }^{6}$ República del Ecuador, Constitución del Ecuador, Articles 10 and 71-74 $<$ http://www.asambleanacional.gov.ec/documentos/constitucion_de_bolsillo.pdf $>$; Julio Marcelo Prieto Méndez, Derechos de la naturaleza: fundamento, contenido y exigibilidad jurisdiccional (Corte Constitucional del Ecuador, CEDEC, 2013).

7 Estado Plurinacional de Bolivia, Ley de Derechos de la Madre Tierra [Law of the Rights of Mother Earth] (21 December 2010) <http://bolivia.infoleyes.com/shownorm.php?id=2689>.

${ }^{8}$ See, Eradicating Ecocide <http://eradicatingecocide.com/the-law/> (on a criminal law oriented approach to 'ecocide'). 
Case 4. An energy company $\mathrm{Y}$ with its seat in State $\mathrm{X}$ would like to produce energy in Ecuador by way of fracking. It wonders whether this is compatible with Ecuador's Constitution, in particular Articles 10 and 71-74. Moreover, it wonders whether it should opt for dispute resolution by way of arbitration under a bilateral investment treaty (BIT) concluded between Ecuador and State $\mathrm{X}$ or under the conventional court system. One group of students puts forward arguments showing why fracking should be fine under the Constitution and in favour of arbitration; another group of students puts forward arguments against fracking under the Constitution and in favour of the conventional court system; a third group of students decides on both issues. ${ }^{9}$

\section{EXTRACTION OF RESOURCES AND DEFORESTATION}

Case 5. European legislation envisages transparency requirements for issuers whose securities are admitted to trading on a regulating market and which have activities in the extractive or logging of primary forest industries. ${ }^{10}$ In particular, payments to governments in the countries where these issuers operate should be reported. Students are invited to incorporate this approach into draft provisions to be elaborated by them for potential inclusion in the UNIDROIT Legislative Guide on Enhancing Trading in Securities in Emerging Markets $^{11}$ (which is intended, or should in this context be considered to be intended, to apply to developed markets as well). In doing so, they should evaluate what natural resources merit protection, whether mere transparency of issuers is sufficient, or whether they wish to envisage complementary, more robust mechanisms, also in relation to other actors (investors, financial intermediaries, etc.) Eg: an outright prohibition of trading of securities of certain issuers; imposing conditions for the admission of securities of certain

9 See, Claire Provost and Matt Kennard, The Obscure Legal System That Lets Corporations Sue Countries (10 June 2015)<http://www.theguardian.com/business/2015/jun/10/obscure-legal-systemlets-corportations-sue-states-ttip-icsid >; Stanisław Sołtysiński, 'The Importance of the Principles of Equality of the EU Member States and Economic Actors in EU Law' (2014) 2 ELTE L J73, para II.4 (on BITs).

${ }^{10}$ See, Directive 2013/50/EU of 22 October 2013, recitals (7) and (8) and Article 1(5) (replacing Article 6 of Directive 2004/109/EC); Directive 2013/34/EU of 26 June 2013, Chapter 10; Extractive Industries Transparency Initiative $<$ http://www.eiti.org $>$.

${ }^{11}$ UNIDROIT, Study LXXVII B-Principles and Rules Capable of Enhancing trading In Securities in Emerging Markets (December 2015) < http://www.unidroit.org/work-in-progress-studies/currentstudies/emerging-markets>. 
issuers to trading (eg measures to compensate the damaging effects of extraction or logging, a 'net zero impact' or 'carbon capture and storage' certificate, or a cap on payments to governments); requiring parties holding an interest in securities issued by certain issuers to be transparent about the volume of their holding; and imposing requirements as to voting behaviour in relation to certain issuers by shareholders or their proxies (eg proxies must receive explicit instructions in respect of certain decisions). ${ }^{12}$ Moot negotiations on the draft provisions could be held between students representing exporting and importing countries.

Case 6. Students are asked to draw up a legal risk profile for their employer, a company in State $\mathrm{X}$ that intends to exploit a variety of resources in part of a rain forest (timber, palm oil, etc) in State Y. Issues that could be included are: government regulation; permits; organization of the land registry (eg on a local and/or centralized level) and its quality; native land rights; selfregulatory industry standards for certain commodities; import limitations on certain commodities by States; reporting obligations regarding payments made by enterprises to States (see Case 5); civil and/or criminal liability; analysis of the (potential) impact of court cases on behalf of future generations (eg in the Netherlands, the Philippines, the US) regarding the long-term effects of exploitation of natural resources (see Case 2); etc.

Case 7. The extraction of so-called 'rare earth' minerals, which are used in the production of a wide range of technological devices (magnets, cars, mobile phones, TV screens, etc.) has a far-reaching social and environmental impact. Think of the toxic lake in Baotou in China. ${ }^{13}$ Students are asked to write an essay or conduct in-class presentations on the legal aspects of this phenomenon. These include licensing by governmental authorities, civil and/or criminal liability for the deterioration of human health and environmental

\footnotetext{
${ }^{12}$ See, Oxford Martin School, University of Oxford, Net Zero Carbon Investment Initiative <http://www.oxfordmartin.ox.ac.uk/research/programmes/carbon-investment $>$; Helen Briggs, Fossil Fuels: Scientists Draw up Investment Principles (21 March 2015) $<$ http://www.bbc.com/news/science-environment-31872459>; Terry Macalister, Fossil Fuel Companies 'Should Be Made to Invest in Carbon Capture and Storage'(2 July 2015) $<$ http://www.theguardian.com/environment/2015/jul/o2/fossil-fuel-companies-should-be-made-toinvest-in-carbon-capture-and-storage $>$; Financial Stability Board (FSB), FSB to Establish Task Force on Climate-related Financial Disclosures (4 December 2014) <http://www.fsb.org/2015/12/fsb-toestablish-task-force-on-climate-related-financial-disclosures/>.

${ }^{13}$ See, Tim Maughan, The Dystopian Lake Filled by the World's Tech Lust (2 April 2015) $<$ http://www.bbc.com/future/story/20150402-the-worst-place-on-earth $>$.
} 
pollution, and human rights (including the rights to health, water, food, and a clean environment). As to liability, the question is who is liable: the enterprises that extract the minerals at source, the government that provides licenses/permits, the companies that process the raw materials in third States into marketable products, the financial institutions that provide financing, consumers, or yet other actors? If placed in the setting of the Arctic or Antarctic territories or the seabed, students could additionally be asked to elaborate on the public international law aspects of the (potential) extraction of rare minerals (who 'owns' certain territories?). ${ }^{14}$

\section{Newly Created Materials: Plastics}

The widespread use of plastics has become a considerable problem since the invention of a first type of plastic about a century ago, as plastics are often not or not easily bio-degradable. They are part of a much wider human waste issue. An enormous quantity of plastics is currently present in the earth's water systems, in the oceanic gyres in the Indian, North Atlantic, North Pacific, South Atlantic and South Pacific Oceans, and elsewhere, in the form of larger, microand nano-plastic particles. These (and the harmful substances they contain and absorb) are eaten by fish, birds, and other animals, and through them and through plants also enter into the human food chain.

This development has triggered a range of new approaches. Examples are the invention of a technique for cleaning up at least part of the plastic in the oceans or for the decomposition of plastics (e.g., by way of fungi); the development of new alternatives for plastics (again, e.g., fungi); the use of recycled plastic (e.g., for the production of sports shoes or the construction of roads); and the appearance of package-free stores.

Case 8 . Students are asked to work on the legal aspects of these new approaches, presenting their results in papers or in-class presentations. A first legal aspect are patents and intellectual property rights protecting (investments in) new inventions and approaches, e.g., in relation to inventions for the clean-

${ }^{14}$ Organisation for Economic Co-operation and Development, OECD Due Diligence Guidance for Responsible Supply Chains of Minerals from Conflict-Affected and High-Risk Areas (2013; second edition) $<$ http://www.oecd.org/corporate/mne/mining.htm $>$. 
up of the oceans, decomposition of plastics, or alternatives for plastics (cf. Case 9). Secondly, students could work on the issue of who is responsible (or liable) for plastic in oceans from an international law perspective. A third research field is the legal aspects of structuring and financing of new approaches relating to plastics. E.g., what legal form do you choose for a new enterprise focused on package-free sales; the legal aspects of other constructions to finance innovative start-ups (e.g., by way of crowd funding, venture capital, the issuance of debt securities, bank financing, etc). ${ }^{15}$

\section{Food: Transgenetic Modification}

Over the past decades, the transgenetic modification of living organisms has become booming business. In particular, genetically modified plants are the subject of commercial practice, whereas animals are (still) largely the subject of experiments (aside from the consideration that they may be fed genetically modified plants). Genetic modification of plants and related issues, such as the impact of the use of pesticides, biodiversity, food security for a growing population, and the economic and social impact of commercial control over and exploitation of seeds, have given rise to intense debate. These developments also raise a range of intricate legal issues.

\footnotetext{
${ }^{15}$ Associated Press, Up to 90\% of Seabirds Have Plastic in Their Guts, Study Finds (1 September 2015) < http://www.theguardian.com/environment/2015/sep/o1/up-to-9o-of-seabirds-have-plastic-intheir-guts-study-finds>; Leah Borromeo, Berlin Duo Launch a Supermarket with No Packaging (16 September 2014) <http://www.theguardian.com/sustainable-business/2014/sep/16/berlin-duosupermarket-no-packaging-food-waste>; Helen Briggs, Mediterranean Sea 'Accumulating Zone of Plastic Debris' (2 April 2015) <http://www.bbc.com/news/science-environment-32145976>; Gordon Darroch, Crazy Paving: Rotterdam to Consider Trialling Plastic Roads (10 July 2015) $<$ http://www.theguardian.com/world/2015/jul/10/rotterdam-plastic-roads-trial-netherlands $>$; Bram Menglers (documentary director), Fungus: The Plastic of the Future (2015)

$<$ https://www.youtube.com/watch?v=jnMXH5TqqG8 >; Stanisław Sołtysiński, 'The Importance of the Principles of Equality of the EU Member States and Economic Actors in EU Law' (2014) 2 ELTE LaW Journal 73, section II.3 (on intellectual property rights); Liz Stinson, A Mini Farm That Produces Food from Plastic-Eating Mushrooms (22 December 2014) <http://www.wired.com/2014/12/minifarm-produces-food-plastic-eating-mushrooms/>; Emma Thomasson, Adidas to Use Marine Plastic Waste in Products from 2016 (20 April 2015) <http://www.reuters.com/article/2015/04/20/us-adidasenvironment-idUSKBNoNBoNK20150420>; Wageningen University, Microplastics and nanoplastics research portal <http://www.wageningenur.nl/en/Dossiers/file/Microplastics-and-Nanoplastics.htm $>$; The Ocean Cleanup <http://www.theoceancleanup.com $>$.
} 
Case 9. A number of these legal issues come to the fore in the critical documentary The World According to Monsanto. ${ }^{16}$ Students are instructed to present the legal issues mentioned in this documentary, or to identify and evaluate them in a paper. The legal issues referred to in the documentary include aspects of criminal law, labour/employment law, civil law suits (e.g., damages claimed for the unauthorized use of seeds, the threat of legal proceedings if corporate information is disclosed in a labour/employment dispute), 'technology/stewardship agreements', liability for asserted environmental impact (e.g., pollution of the soil by pesticides; reduction of animal life, including bees, and plant varieties; cross-pollination), liability for asserted health impact (due to the use of pesticides and/or the consumption of GMOs), the civil and company law aspects of (international) take-overs of seed companies, regulatory law, human rights (including those relating to health, food, a clean environment, and other economic and social rights, as well as the rights of children, women, minorities, and indigenous peoples), (the exploitation of) patents and other intellectual property rights (cf. on this issue Case 8), and trade agreements between States. ${ }^{17}$

\section{WATER}

\section{A Freshwater}

The quantity and quality of freshwater is high on the policy agenda. While climate change affects the availability of resources, an ever growing world population requires more and more water for drinking, washing, irrigation of agricultural land, etc. One of many telling examples is the recent scarcity of freshwater in California due to extreme drought combined with

\footnotetext{
${ }^{16}$ Marie-Monique Robin (documentary director), The World According to Monsanto (2008).

${ }^{17}$ See, Matt McGrath, Global Warming Increases 'Food Shocks' Threat (14 August 2015) $<$ http://www.bbc.com/news/science-environment-33910552 >; Paul Moreira (documentary director), Bientôt dans vos assiettes (de gré ou de force) (2014); Andrew Pollack, Genetically Engineered Salmon Approved for Consumption (19 November 2015) $<$ http://www.nytimes.com/2015/11/20/business/genetically-engineered-salmon-approved-forconsumption.html> ; Stanisław Sołtysiński,'The Importance of the Principles of Equality of the EU Member States and Economic Actors in EU Law' (2014) 2 ELTE L J 73, section II.3 (on intellectual property rights); John Travis, 'Making the Cut: CRISPR Genome-editing Technology Shows Its Power' (2015) 350/6267 Science, 1456-1457; UNIDROIT, FAO and IFAD, UNIDROIT/FAO/IFAD Legal Guide on Contract Farming (2015).
} 
intensive agriculture, requiring radical readjustment measures. ${ }^{18}$ The quality of freshwater is affected by the widespread use of agricultural pesticides, hydraulic fracturing ('fracking') chemicals, medicines, etc. The establishment in 2003 of UN-Water, the United Nations inter-agency coordination mechanism for freshwater- and sanitation-related issues, underlines the importance of freshwater from a public policy perspective. Commercial enterprises also have an interest in control over freshwater sources. ${ }^{19}$

Case 10. Students are instructed to identify and evaluate the legal aspects in the documentary Bottled Life (and/or Tapped) ${ }^{20}$ on water extraction and bottling by commercial entities. These include State laws (such as the one in Maine, intended to give settlers the right to withdraw as much water as they needed to live and farm); government regulation (permits, administrative proceedings, etc); constitutional law; human rights (access to water); public or private 'ownership' of water; civil law aspects (e.g., to whom does a single water reservoir under several parcels of land belong?; buy/sale transactions in respect of water rights; civil law suits to enforce rights to extract water).

Case 11. Some additional legal questions arise in the context of ancient water reservoirs being discovered kilometers down in the earth crust $^{21}$, on which students can be asked to elaborate. What are the financing and intellectual property law aspects of developing new machinery for investigating and possibly extracting the underground water resources? Does anyone have a

\footnotetext{
${ }^{18}$ See, Alastair Leithead, California Drought: Drilling Deeper in the Hunt for Water (27 August 2014) $<$ http://www.bbc.com/news/magazine-28930485>.

${ }^{19}$ See, Rose Hackman, Nestle Bottled Water Operations Spark Protests amid California Drought (20 May 2015) <http://www.theguardian.com/us-news/2015/may/20/nestle-water-bottling-californiadrought $>$; Bryan Brooks and Duane Huggett (eds.), Human Pharmaceuticals in the Environment: Current and Future Perspectives (Springer, 2012); Brian Owens, 'Pharmaceuticals in the Water: A Growing Problem' (2015) 294/7850 The Pharmaceutical Journal <http://www.pharmaceuticaljournal.com/news-and-analysis/features/pharmaceuticals-in-the-environment-a-growingproblem/20067898.article>; US Geological Survey (USGS), Science for a Changing World, Scientists Contribute to New Book on Pharmaceuticals in the Environment,

$<$ http://toxics.usgs.gov/highlights/pharmaceuticals.html> (with links to additional scientific sources); Scientists Take to the Stage on Climate Change (9 February 2015)

$<$ http://www.bbc.com/news/science-environment-31091820 $>$ (on a futuristic theatre performance on water shortages involving scientists); UN-Water: $<$ http://www.unwater.org/>.

${ }^{20}$ Urs Schnell (documentary director), Bottled Life: The Truth about Nestlés Business with Water [Nestles Geschäfte mit Wasser] (2011) <http://www.bottledlifefilm.com/>; Stephanie Soechtig and Jason Lindsey (documentary directors), Tapped (2009) <http://www.tappedthemovie.com/>.

${ }_{21}$ See, Rebecca Morelle, Volume of World's Oldest Water Estimated (18 December 2014) $<$ http://www.bbc.com/news/science-environment-30527357>.
} 
claim to this water so deep down from a public international law perspective? What is the analysis where water reservoirs cross (perceived) national borders?

\section{B Commercial activity relating to seas and oceans}

The world's seas and oceans are the theatre of large-scale economic activity. If we confine ourselves to focus only on the sea and ocean beds, then fishing, the laying of cables and pipes, and the winning of oil, gas and other resources spring to mind. Techniques used include bottom trawling, dredging, rock sinking and positioning, and extraction. Specialized companies offer research services regarding the sea and ocean beds (using satellites, sonar, etc) in order to make such economic activity possible.

Case 12. Students are asked to come up with a legal framework for trawling. Issues to be covered include a public international law analysis (who is or should be 'entitled' to carry out economic activity in relation to the sea/ocean bed, and where?); national policies, including protected zones; liability for damaging pipes/cables and other structures on the sea and ocean beds; liability for the long-term consequences of trawling (availability of food, environmental impact). A variation of this case would be to ask students to explore in how far rules on trawling can be applied to rock sinking and positioning activities. ${ }^{22}$

\section{The Atmosphere: RAdiAtion}

Radiation exists in many forms. The case proposed here by way of example focuses on radiation for mobile communication.

Case 13 (moot court). Students are split into three different groups. One group acts as the lawyers in joint proceedings initiated by a farming

\footnotetext{
${ }^{22}$ See, Marine Population Halved Since 1970 - Report (16 September 2015) $<$ http://www.bbc.com/news/science-environment-34265672>; Mark Kinver, Study Identifies Fish Vulnerable to Trawling ( 5 August 2015) $<$ http://www.bbc.com/news/science-environment33771553 >; Robin McKie, Bottom Trawling: How to Empty the Seas in Just 150 Years (10 February 2014) $<$ http://www.theguardian.com/environment/2014/feb/10/bottom-trawling-how-to-empty-theseas $>$; 'Bottom trawling' Wikipedia $<$ https://en.wikipedia.org/wiki/Bottom_trawling\#Current_restrictions $>$ (with a list of legal regulations regarding bottom trawling).
} 
corporation (which claims that radiation for mobile communication has exterminated bees, making pollination and harvest virtually impossible) and individuals (who assert that such radiation has had a damaging effect on their health, leading to personal expenditures and costs for the national health system) in State X. The defendants, represented by another group of students, are antenna providers and mobile telephone companies in State $\mathrm{X}$ and the International Commission on Non-Ionizing Radiation Protection based in Germany, which commission, according to claimants, has provided inadequate scientific advice and guidance, on which authorities and companies worldwide have relied to set exposure limits to telephone-related radiation. A third group of students acts as judges. Legal issues to be discussed include: applicable law; liability for asserted economic losses, environmental consequences, and health costs; the role of governmental and non-governmental standard-setting bodies. ${ }^{23}$

\section{OUTER SPACE}

An ever-increasing amount of space debris is in orbit around the earth at enormous speeds, with potentially damaging effects on other objects in space (satellites and other space assets, affecting such currently common applications as mobile telephones, television broadcasting, and navigation systems, to name but a few) and in case space debris hits territory on earth. Until recently, space was predominantly the realm of States and space agencies. The new trend towards a (potential) increase in commercial activity by private entities in space is likely to aggravate the problem of space debris.

Case 14. Students are invited to establish a link between, on the one hand, the imminent 'commercialization of outer space' and the international convention that deals with commercial law/financing aspects of space assets (i.e., the Protocol on Matters Specific to Space Assets to the so-called Cape Town Convention) and, on the other hand, the broader consequences of such developments, in particular the increase in space debris. The students are asked

\footnotetext{
${ }^{23}$ See, Nina Hendy, Tiny Trackers Could Help Solve Global Bee Death Mystery (25 August 2015) $<$ http://www.bbc.com/news/world-australia-34048495>; Leo Kelion, Googles Project Loon Internet Balloons to Circle Earth (28 October 2015) <http://www.bbc.com/news/technology-34660205>; James Russell and John Webster (documentary directors), Resonance: Beings of Frequency (2012); ICNIRP, International Commission on Non-Ionizing Radiation Protection <http://www.icnirp.org/>; World Health Organization, Electromagnetic fields (EMF) < http://www.who.int/peh-emf/en/>.
} 
to draft a supplementary protocol to the Cape Town Protocol addressing space debris as the consequence of financing/commercial activity, including questions like: In what ways can space debris be limited? Who is or should be legally responsible for damage to assets in space or on earth caused by space debris or for cleaning it up? ${ }^{24}$

\section{CONCLUSION}

Commercial activity since the industrial revolution has been a core driver of change at unprecedented speed and with ever more visible, farreaching consequences. Traditional commercial and financial law teaching no longer does the job. A new, more holistic approach is needed, which takes into account the limited availability of natural resources and the potentially catastrophic impact of their unlimited exploitation. The proposed method of integrating case studies involving natural resources into the mainstream curriculum is easy to implement. Students are invited to investigate a broad range of legal issues on the crossroads of commercial activity and natural resources, and to present their findings in papers, in-class presentations, moot court cases, moot intergovernmental negotiations, etc. Following this or other, comparable methods will equip a future generation of commercial and finance lawyers with the knowledge to contribute to responsible choices.

${ }^{24}$ See, Hugh Lewis, Trouble in Orbit: the Growing Problem of Space Junk (5 August 2015) $<$ http://www.bbc.com/news/science-environment-33782943>; Jonathan Amos, Virgin Boosts Rocket Capability (15 September 2015) <http://www.bbc.com/news/science-environment-34254873>; InterAgency Space Debris Coordination Committee <http://www.iadc-online.org/> including an overview of currently existing Space Debris Mitigation Policies, Guidelines, and Standards (link to References); Roy Goode, Herbert Kronke, Ewan McKendrick (eds), 'International Interests in Mobile Equipment and the Cape Town Convention and Aircraft Protocol: Adding a New Dimension to International Lawmaking' in Transnational Commercial Law Texts, Cases and Materials (Oxford University Press; $2^{\text {nd }}$ ed, 2015) 393-423; Protocol to the Convention on International Interests in Mobile Equipment on Matters Specific to Space Assets, opened for signature 9 March 2012 $<$ http://www.unidroit.org/instruments/security-interests/space-protocol>. 
